\title{
BIBECHANA
}

ISSN 2091-0762 (Print), 2382-5340 (Online)

Journal homepage: http://nepjol.info/index.php/BIBECHANA

Publisher: Department of Physics, Mahendra Morang A.M. Campus, TU, Biratnagar, Nepal

\section{Degradation of fundamental polymers/plastics used in daily life: a review}

\author{
Netra Lal Bhandari*1, Ganesh Bhandari ${ }^{1}$, Sunita Bista ${ }^{1}$, Basant Pokhrel ${ }^{1}$, Kabita Bist ${ }^{1}$, Kedar Nath \\ Dhakal $^{2}$ \\ ${ }^{1}$ Department of Chemistry, Tri-Chandra Multiple Campus, Tribhuvan University, Kathmandu, Nepal \\ ${ }^{2}$ Central Department of Chemistry, Tribhuvan University, Kirtipur, Kathmandu, Nepal \\ *Email: netra.tu.edu@gmail.com
}

\section{Article Information:}

Received: June 24, 2020

Accepted: September 9, 2020

Keywords:

Polyethylene

Polylactic acid

Degradation

Thermogravimetric analysis

\begin{abstract}
Polymers/plastics, composed of monomers in the form of chain/s, are one of the highly used materials for different purposes in daily life. Abiotic and biotic processes carry out degradation of polymers. Abiotic pathway occurs from thermal, catalytic and photo-degradation methods whereas biotic methods occur in presence of different type of microorganisms. The degradation of representative polymers; petro- and bio-based (polyethylene and polylactic acid respectively) was explained by thermal, catalytic, biodegradation and photodegradation processes. The thermal degradation of polyethylene and polylactic acid was explained by thermogravimetric analysis (TGA) curves. Catalysts such as zeolites and amorphous silica-alumina were used for degradation of polyethylene whereas, tin for polylactic acids. Microorganisms such as bacteria, fungus and actinomycetes help for degradation of polyethylene and polylactic acid. Ultra violet (UV) radiation and hydroperoxides are used for the photodegradation of polymers. Bio-based polymers are found to degrade relatively faster into environmentally compatible fragments in comparison to petro-based polymers. Therefore, it is emphasized on producing bio-based polymers rather than petro-based for sustainability for addressing plastics related global environmental issues.
\end{abstract}

DOI: https://doi.org/10.3126/bibechana.v18i1.29619

This work is licensed under the Creative Commons CC BY-NC License. https://creativecommons.org/licenses/by-nc/4.0/

\section{Introduction}

Daily human life without polymers is hardly expected these days because polymers have become one of the essential materials of twenty first century. Natural (bio-based) and synthetic (petro-based) polymers are being widely used in these days in daily life. The worldwide estimated quantity of plastics production is increasing from 325 million tons (today) to 1100 million tons by 
2050. Most of the plastic materials will end in landfills and more is incinerated till today even though the rate of recycling is going up day by day. Numbers of researches are being carried out for the disposal and degradation of polymers and plastics. Re-use, and recycling of plastics followed by the production of bio-based eco-friendly plastics can be the sustainable tasks for upcoming human generation $[1,2]$. In these days, natural polymers such as cellulose, chitin, lignin, starch, pectin, natural fibers etc. and the secondary materials based on them are the research topics of scientists for different applications such as drug delivery, biocompatible dental, and surgical implants etc. [2]. Similarly, many synthetic plastics such as polyethylene (PE), polyvinyl chloride (PVC), polystyrene (PS), polypropylene (PP) etc. are being used for packaging and other household applications because of their low weight, low cost and durability [3,4]. Meanwhile, they contribute to the existing disposal and degradation problems in maximum. Their manufacturing includes different organic and inorganic materials such as carbon, hydrogen, oxygen, nitrogen, chlorides, coal and natural gases [3-5].

Polylactic acid (PLA), one of the most widely used bio-plastic, exhibits high stiffness, low toughness, transparency, biocompatibility, biodegradability etc. [5]. It has a very slow crystallization rate containing high level of crystallinity as end products that dictates most of the mechanical and thermal properties [6,7]. The ductility and toughness of PLA have been improved following multiple strategies such as copolymerization, plasticization, melt blending etc. with different tough polymers, rubbers and elastomers [6-11]. PLA is available in the market at a price on a par with that of common plastics like polypropylene [5].

Polymer degradation can be a set of complicated processes whose actual mechanism/s has not been explained till now. Mostly, the degradation of polymers occurs by abiotic or biotic pathways.
Abiotic pathways refer to thermal, photochemical and oxidative processes whereas microorganisms and enzymes carry out biotic degradation [12-14]. Photodegradation of polymers also occurs via homolytic bond celevage of ester like bonds followed by free radical chain mechanism in presence intense solar UV radiations $[12,14]$.

Biodegradation (enzymatic degradation) of polymers by the action of metabolic microorganisms such as bacteria, algae and fungi etc in presence of atmospheric oxygen from which small molecules or fragments are released into environment. This process is based on the concept of 'Carbon Neutrality' by which the generated carbon dioxide is again converted into biomass by photosynthesis [15-21]. Chemical structure, functional groups, reactivity, swelling behavior hydrophilicity etc are the factors affecting the biodegradability of polymers [22,23]. Pseudomonas, Streptomyces, thermoactinomycetes, Klebsiella, Actinomycetes, Nocardia, Micromonospora, Flavobacterium, Comamonas, Escherichia, Mycobacterium, Rhodococcus, Azotobacter, Alcaligenes, etc., are the common bacteria identified contributing to polymeric biodegradation [23,24]. Similarly, Sporotrichum,

Talaromyces, Thermoascus, Thielavia, paecilomyces, Phanerochaete, Ganoderma, Geotrichum, Cladosporium, Phlebia, Trametes, Candida, Penicillium, Chaetomium, Aerobasidium, etc. are the fungi identified so far taking part in polymer degradation $[25,26]$. It has been found from the research works that bio-based polymers degrade earlier in comparison to petro-based polymers/plastics [23].

This paper presents a brief review on advances in degradation of PLA and PE as representative examples of bio-based and petro-based polymers respectively. Thermal, bio- and photo-degradation of these polymers along with some results/data from the literature are taken into account for the discussion. The idea will be supportive to focus the polymeric research particularly on bio-based polymers, finding the cross-linking reagent/catalyst 
that easily polymerizes the corresponding biomonomers to bio-polymers for future prototype materials building, and the sustainability. It will also be useful to explain the real mechanism of polymer degradation and composting phenomenon that is remained poorly defined in polymer research till yet.

\section{Thermal degradation of PE}

Thermal degradation of polymers is experimentally performed under an inert atmosphere and the process is called pyrolysis/thermolysis. The most commonly followed method is the thermogravimetric analysis (TGA). In this method, 15 to $20 \mathrm{mg}$ of polymer, taken in a platinum pan hanged with a spring is heated up to $600{ }^{\circ} \mathrm{C}$ [27-29]. Abbas-Abadi (2020), reported the degradation of $\mathrm{PE}$ at $650-850 \mathrm{~K}$ in $\mathrm{N}_{2}$ atmosphere at the heating rate of $30 \mathrm{~K} \mathrm{~min}^{-1}$ [30]. The TGA curve of PE is presented in Fig. 1 [28].

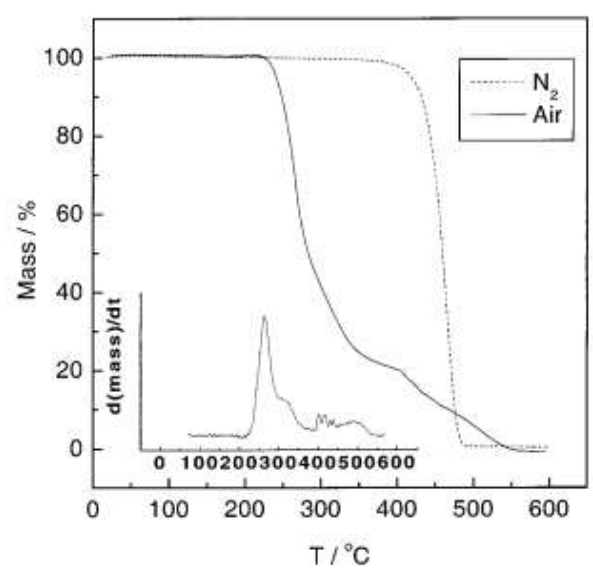

Fig. 1: TGA curves of PE under nitrogen (dashed line) and air (solid line) (heating rates of 9.2 and 9.0 $\mathrm{K} \mathrm{N} \mathrm{m^{-1 }}$ for nitrogen and air, respectively). Inset: derivative plot of weight loss for degradation in air [28].

Figure 1 shows that $\mathrm{PE}$ is degraded in a single step that begins at $350^{\circ} \mathrm{C}$ and reached zero mass at $490^{\circ} \mathrm{C}$ in $\mathrm{N}_{2}$ atmosphere. However, degradation curve possesses some irregular trends in presence of air. The degradation of PE begins at $220^{\circ} \mathrm{C}$ and reaches zero mass at $550{ }^{\circ} \mathrm{C}$ that might be for the oxidation at first, and degradation steps at the end.
The thermal degradation of PE in presence of catalysts performs different behavior with respect to product yield. The catalysts such as zeolites, amorphous silica-alumina etc. are used for effective thermal degradation of PE for the increased rate of reaction [31-34]. The use of amorphous silicaalumina, during thermal degradation of $\mathrm{PE}$ significantly reduced the activation energy in comparison to thermal processes without catalyst/s [33-40]. The catalyst ( $10 \%$ by w/w of polymer catalyst ratio), dependent yields of thermal degradation of $\mathrm{PE}$ at $560{ }^{\circ} \mathrm{C}$ are presented in Table 1.

\section{Thermal degradation of PLA}

The mechanism of PLA degradation by pyrolysis is shown in Fig. 2. The thermal degradation of PLA is a complex phenomenon consisting of a random main-chain scission and unzipping or decompress depolymerization reaction [41-44]. The random degradation involves intramolecular and intermolecular trans-esterifications, cis-elimination and other reactions such as hydrolysis or oxidative degradation whereas, unzipping or decompress depolymerization occurs when terminal hydroxyl groups became more concentrated [42,44-46].

Thermal degradation of PLA is also studied using thermogravimetric analysis (TGA) [47-51]. The heating rates of $5,10,20,30,40{ }^{\circ} \mathrm{C} \mathrm{min}{ }^{-1}$ were used which is shown in Fig. 3 (a). The TGA curves of PLA showed single decomposition peak at lower heating rate, the retention time required for the PLA to a given temperature is longer [52]. The pyrolysis of PLA was carried out in presence of catalyst. Many researchers have explained the effect of catalyst in pyrolysis behavior of PLA in literatures [44,52-57]. Organo-catalyst such as 1,5,7-Triazabicyclo[4.4.0]dec-5-ene (TBD) and 4pyrrolidinopyridine also helps in degradation of PLA [58]. The TGA curves for pyrolysis of PLA in presence of tin as catalyst is shown in Fig. 3 (b) which shows that the degradation temperature for PLA decreases as the composition of tin increases [53]. 
Table 1: Catalyst dependent product yield in the pyrolysis of $\mathrm{PE}$ at $560^{\circ} \mathrm{C}$ [40].

\begin{tabular}{lccccc}
\hline Catalyst & \multicolumn{5}{c}{ Percent Products } \\
\hline & Ethylene & Propylene & Isobutylene & 1-hexene & Heptane \\
\cline { 2 - 6 } None & 39.98 & 19.52 & 19.41 & 17.24 & 12.84 \\
$\mathrm{Al}_{2} \mathrm{O}_{3}$ (basic) & 29.02 & 15.53 & 18.20 & 22.57 & 15.61 \\
$\mathrm{Al}_{2} \mathrm{O}_{3}$ (neutral) & 25.67 & 15.21 & 17.59 & 24.09 & 17.43 \\
$\mathrm{SiO}_{2}$ & 26.39 & 11.48 & 17.70 & 22.97 & 13.40 \\
$\mathrm{Zeolite}$ & 23.19 & 11.39 & 17.39 & 28.40 & 17.04 \\
\hline
\end{tabular}

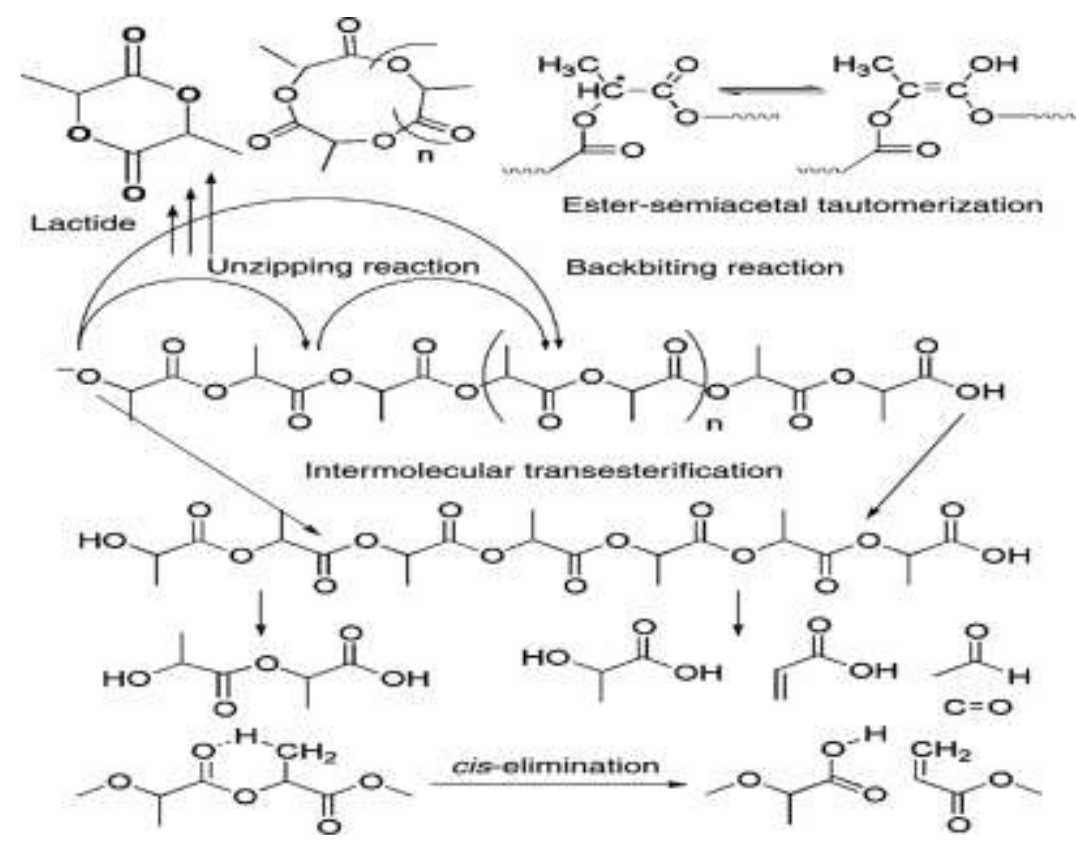

Fig. 2: Thermal degradation of PLA and pyrolysis mechanism [44].
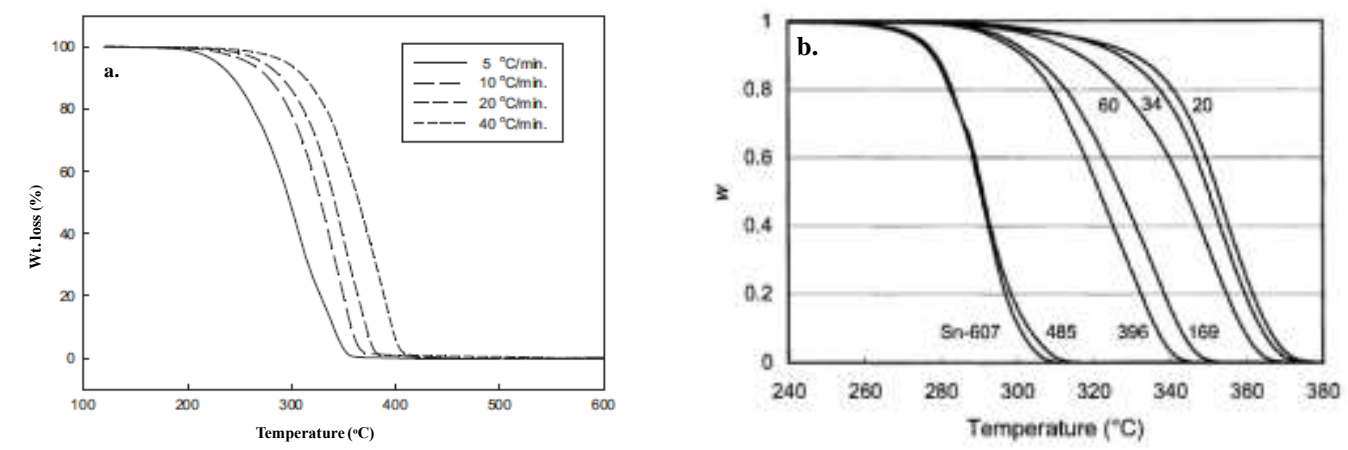

Fig. 3: (a) TGA curves of PLA at different heating rates $\left(5,10,20\right.$ and $\left.40{ }^{\circ} \mathrm{C} \min ^{-1}\right)$ under $\mathrm{N}_{2}$ (b) TGA curves of PLA-Sn samples at a heating rate of $5 \mathrm{~K} \mathrm{~min}^{-1}$ under $\mathrm{N}_{2}$ flow of $100 \mathrm{~mL} \mathrm{~min}{ }^{-1}[52,53]$. 
Thermal degradation of bio-based polymer and petro-based polymer occurs by pyrolysis in presence of air or nitrogen. Various catalysts support the pyrolysis mechanism. Catalyst such as zeolites and amorphous silica-alumina are used for degradation of polyethylene whereas, tin for polylactic acid. The temperature required for pyrolysis of polyethylene in presence of catalysts is higher than that of polylactic acid. Therefore, degradation of bio-based polymers required less energy and faster process than petro-based polymers.

\section{Biodegradation of PE}

$\mathrm{PE}$ is a representative of synthetic homo-polymers that contain repeating units of $-\mathrm{CH}_{2}-\mathrm{CH}_{2}$ - as a monomer in the polymer backbone [3]. Biodegradation/composting of homopolymers is reported to occur in decades by bond cleavage with the enzymatic action of microorganisms [59]. The degradation of $-\mathrm{CH}_{2}-\mathrm{CH}_{2-}$ backbone can be enhanced by the addition of readily biodegradable compounds, such as starch, to a low-density polyethylene matrix etc. [15].

Some researchers have explained the composting and biodegradation as synonymous terms but others have different arguments that in composting not only the solo microorganisms but also the microorganisms, enzymes, fungi, heat, temperature, light and moisture acts simultaneously for the degradation [60-65]. Devi et al. (2015), Hadad et al. (2005), Abrusci et al. (2011), Sowmya et al. (2014), Nowak et al. (2011), Usha et al. (2011), Bonhomme et al. (2003) and Sepulveda et al.(2002) studied the role of different temperature dependent microorganisms and corresponding enzymes for PE degradation. It has been reported that PE breaks down into simpler products (after decades) such as in biofilms, esters, unsaturated hydrocarbons, alkylhalides and others as listed in Table 2 [59-66]. The comparative study of mechanism of bio-degradation and surface morphology of polymers was also explained by spectroscopic, microscopic and thermogravimetric methods.
Similarly, fungal degradation of PE is explained by Corti et al. (2010), on the basis of Fourier transform infrared spectroscopy (FTIR) which is presented in Fig. 4 [67].

The FTIR peaks of polyethylene before and after degradation is different. The dotted line expressed the degradation of polyethylene in 6 month. The FTIR spectra from polyethylene films by the fungal degradation enhance the formation of small units containing carbonyl groups. The FTIR breakdown products in pre-oxidized polyethylene films as reflected by peak intensities on several functional groups. In FTIR spectra several peaks shows the various functional groups such as $-\mathrm{C}=\mathrm{O}\left(1743 \mathrm{~cm}^{-}\right.$ $\left.{ }^{1}\right),-\mathrm{C}=\mathrm{C}-\left(1640 \mathrm{~cm}^{-1}\right),-\mathrm{OH}$ deformation vibration $\left(1080 \mathrm{~cm}^{-1}\right)$ and $-\mathrm{OH}$ stretching vibration $\left(3400 \mathrm{~cm}^{-}\right.$ ${ }^{1}$ ). The appearance of new bands were possibly due to the oxidized fractions such as moieties containing - $\mathrm{OH}$ groups, resulting from the fungal biodegradation [67].

\section{Biodegradation of PLA}

PLA is a bio-based polyester derived from starch feed stocks with a hydrolysable backbone that is susceptible to biodegradation. It is the promising candidate of biodegradable plastic [68] whose biodegradability is based on bacteria such as Bacillus stearothermophilu, Geobacillus thermocatenulatu, fungus, actinomycetes etc. and biochemical processes of degradation have been advanced in recent years [69]. PLA undergoes biodegradation both in aerobic and anaerobic conditions [69]. It is a complex chemical hydrolysis process in presence of soil microorganism in which ester bonds of PLA cleavage into carboxylic acid and alcohol with hydrion (enzyme) [69]. The different steps and possible mechanism of degradation is summarized in Fig. 5.

As in Fig. 5 during biodegradation, PLA-degrading microorganisms first produce extracellular depolymerase of PLA that requires some inducers like elastin, gelatin, silk fibron and some peptides and amino acids [69-71]. 
Table 2: List of some microorganisms and corresponding enzymes contributing to PE degradation.

\begin{tabular}{|c|c|c|c|c|}
\hline Microorganisms & $\begin{array}{c}\text { PE degrading } \\
\text { enzyme }\end{array}$ & $\begin{array}{c}\text { Evolution of new } \\
\text { compounds }\end{array}$ & $\begin{array}{c}\text { Temperature } \\
\left({ }^{\circ} \mathrm{C}\right)\end{array}$ & References \\
\hline Aspergillus tubingensis & - & Biofilm & 45 & {$[60]$} \\
\hline $\begin{array}{l}\text { Brevibacillus } \\
\text { borstelensis }\end{array}$ & - & Biofilm & 30,45 and 50 & {$[59,61]$} \\
\hline Trichoderma harzianum & $\begin{array}{l}\text { Laccase, manganese } \\
\text { peroxidase }\end{array}$ & $\begin{array}{l}\text { Carboxylic acids, } \\
\text { aldehydes, esters, } \\
\text { ethers, and alkyl halides }\end{array}$ & 50 & {$[62]$} \\
\hline $\begin{array}{l}\text { Gliocladium viride, } \\
\text { Aspergillus awamori and } \\
\text { Mortierella subtilissima }\end{array}$ & Bionolle & $\begin{array}{l}\text { Unsaturated } \\
\text { hydrocarbon and } \\
\text { saturated hydrocarbon }\end{array}$ & 27 & {$[63]$} \\
\hline $\begin{array}{l}\text { Streptomyces sp, } \\
\text { Psudomonas sp, Bacillus, } \\
\text { Staphylococcus sp and } \\
\text { Aspergillus sp }\end{array}$ & - & - & 30 & {$[64]$} \\
\hline Rhodococcus rhodochrous & - & Biofilm & 60 & {$[65]$} \\
\hline $\begin{array}{l}\text { Aspergillus niger and } \\
\text { Penicillium pinophilum }\end{array}$ & $\begin{array}{l}\text { Extracellular } \\
\text { enzyme }\end{array}$ & - & 80 & [66] \\
\hline
\end{tabular}
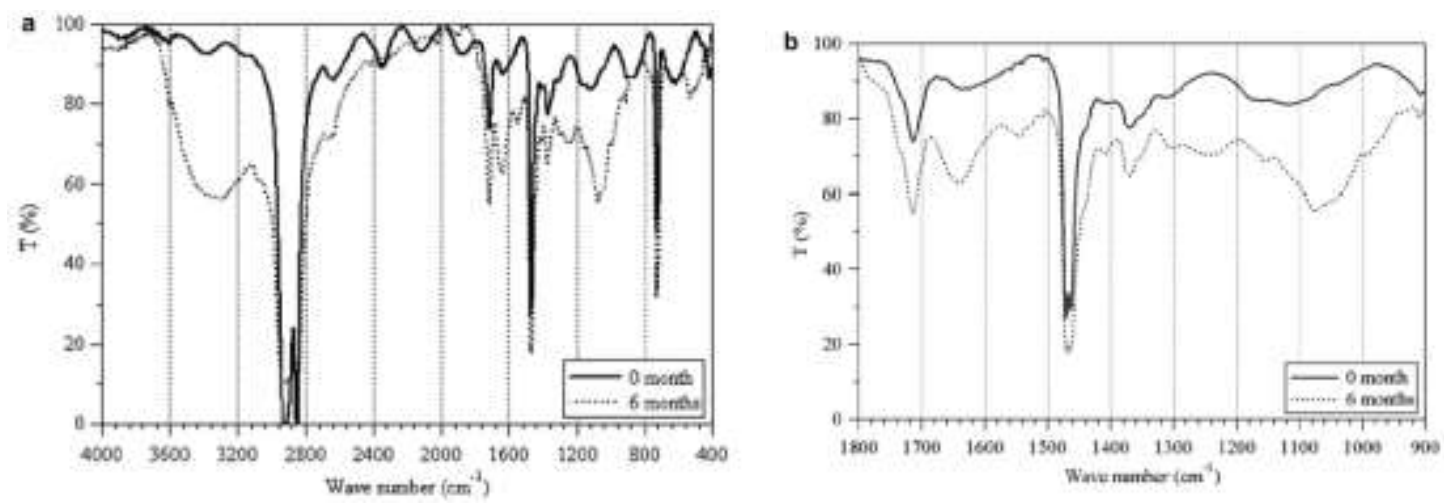

Fig. 4: (a) FTIR spectra of control and pre-oxidized PE films incubation with fungal strain for 6 months (b) magnified region of the spectrum between 900 and $1800 \mathrm{~cm}^{-1}$ of Fig. (a) [67].

The inducers contain L-alanine units, which is similar to L-lactic acid units of PLA. Depolymerase enzyme attack ester units of PLA resulting in the formation of oligomers, dimers and monomers. Finally, it decomposes to carbon dioxide, water and methane [71-74]. Some PLA degrading microorganisms and their corresponding degrading enzymes have been shown in Table 3. Results show that protease is the major enzyme that most of bacteria produce for PLA degradation at $30{ }^{\circ} \mathrm{C}$ [7580].
Chaisu et al. (2013) studied the surface morphology of PLA film after 30 days at $30^{\circ} \mathrm{C}$ by the growth of Aneurinibacillus aneurinilyticus on samples. The surface morphology of PLA film was observed by SEM analysis in secondary electron mode as in Fig. 6 and shows that the PLA film surfaces were smooth in controls before inoculation. However, after bacterial incubation within 30 days shows the surfaces as rough and hemispherical holes as in Fig. 6(b). These SEM micrographs support the PLA films degradation by Aneurinibacillus aneurinilyticus at optimal 
laboratory conditions. Pranamuda et al. (1997), also observed the similar surface morphology of PLA by Amycolatopsis sp $[81,83]$.

The degradation time of bio-based polymers and petro-based polymers is different. For complete degradation, petro-based polymers take a several years and decades as compared to bio-based polymer degradation [84-90]. A comparative study of polymer thin film degradation time in soil has been presented in Table 4. For a complete degradation of polymers in soil takes several years and also depends on thickness of plastic, type of microbes, temperature, moisture content, $\mathrm{pH}$ of soil and soil humus. A thin film of polylactic acid in soil was degraded in 30-35 days and that of polyethylene film in $60-65$ days $[84,88]$. Further, the ether or ester bond containing polymers were degraded earlier as compared to the other hydrocarbon homo polymers.

Above results revealed that both bio-based and petro-based polymers under goes degradation by various microorganisms under different conditions. Microorganisms such as Psudomonas sp and Bacillus helps for maximum degradation of polyethylene as compared to other microorganisms [64]. Similarly, Brevibacillus $s p$ for degradation of polylactic acid [78]. The time required for degradation of bio-based polymer film is less as compared to petro-based polymers. Further, polymers containing the ester, peptide or ether linkage degraded easily in soil with biocompatible end products as compared to hydrocarbon homopolymers. The exact degradation mechanism, isolation and culture of polymers specific bacteria and optimization of conditions for degradation and composting has not been fully studied and practiced till yet, and created the problems for the sustainable polymer waste management.

\section{Photo-degradation of PE}

It is reported that photo-degradation of most of polymers occurs in presence of highly energetic UV radiation following the mechanism of free radical formation similar to that of peroxidation reaction [91-94]. UV radiation with wavelength range of $290-400 \mathrm{~nm}$ can degrade PE into small units compatible to soil such as esters and lactones in presence of hydroperoxide [92,95] as presented in Fig. 7.

\section{Photo-degradation of PLA}

Photo-degradation of Polylactic acid is also carried out in presence of strong UV radiation (200-400 $\mathrm{nm}$ ) with the formation of anhydride and carbonyl groups at the end as final product [96-100]. Bocchini et al. (2010) explained the mechanism of photooxidative degradation of PLA by the chain excision (intrachain $\beta$-scission). The photodegradation of PLA also occurs by Norrish I and II type cleavage, followed by the formation of carbonyl groups as explained in Fig. 8 [97,98]. In this mechanism the anhydride groups are formed by radicals that react with oxygen and extract a hydrogen forming hydroperoxide [98-100].

The photo-degradation of petro- and bio-based polymers more often than not takes place in presence of UV radiations. The polyethylene is not easily decomposed to esters and lactones since it requires large amount of energy and high mechanical pressure. The photo-degradation of polylactic acid is relatively easier with esters and acids as common end products. Therefore, biobased polymers as well as the polymers containing the ester, peptide, ether, carbonyl or amide linked polymers are relatively easier for photodegrdadation to soil compatible products as compared to polyethylene, polyvinyl choloride, polypropylene polymers.

\section{Recommendation for future work}

Many researchers proposed and explained polymer degradation in different ways. However, none of them is found absolute with respect to time, cost as well as environmental concerns. Although composting or biodegradation of polymers seems to be an effective solution of polymer waste disposal, the exact degradation mechanism, isolation and culture of polymer specific microorganisms in laboratory is still missing. This review recommends researchers/readers to focus on green techniques/catalysts for polymerization of natural and bio-based monomers that contain the carbonyl, peptide or ether linkage, and easily degrades by composting or low intensity of UV radiations forming the eco-friendly end products. 


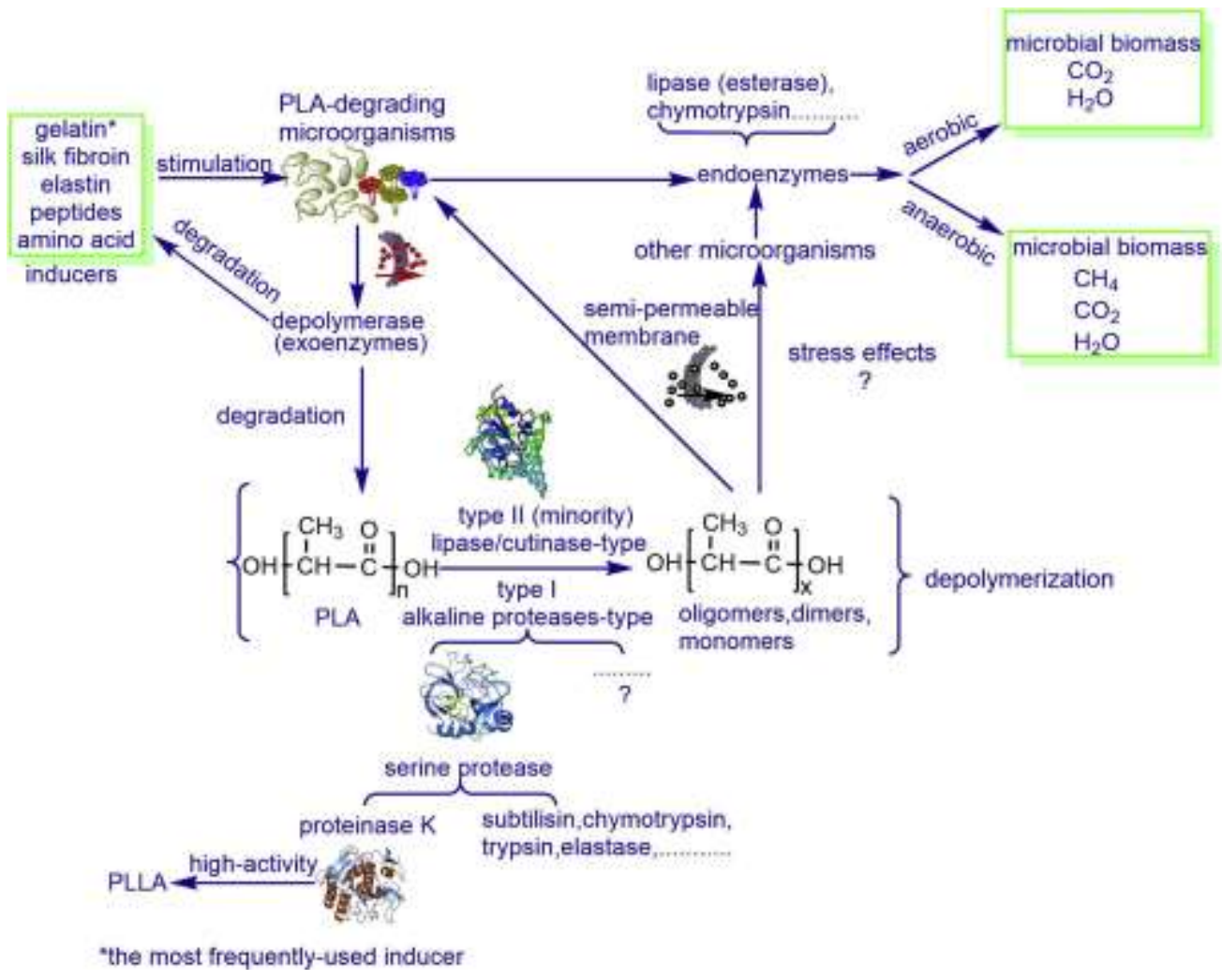

Fig. 5: Schematic diagram of biochemical processes in PLA degradation [Qi et al. (2017)].

Table 3: PLA degrading microorganisms and corresponding enzymes.

\begin{tabular}{|c|c|c|c|c|}
\hline Microorganisms & $\begin{array}{c}\text { PLA degrading } \\
\text { enzyme }\end{array}$ & $\begin{array}{c}\text { Evaluation } \\
\text { of degradability }\end{array}$ & $\begin{array}{l}\text { Optimum } \\
\text { Temp. }\left({ }^{\circ} \mathrm{C}\right)\end{array}$ & References \\
\hline $\begin{array}{l}\text { Amycolatopsis sp. } \\
\text { strain } 3118\end{array}$ & Protease & L-PLA, film weight & 30 & [75] \\
\hline $\begin{array}{c}\text { Amycolatopsis sp. } \\
\text { strain } 41\end{array}$ & Protease & $\begin{array}{l}\text { L-PLA, silk powder, } \\
\text { casein, film weight }\end{array}$ & 30 & $\begin{array}{l}76] \\
\end{array}$ \\
\hline $\begin{array}{c}\text { Lentzea } \\
\text { waywayandensis }\end{array}$ & Protease & L-PLA, film weight & 30 & [77] \\
\hline $\begin{array}{c}\text { Kibdelosporangium } \\
\text { aridum }\end{array}$ & Protease & L-PLA, film weight & 30 & [78] \\
\hline $\begin{array}{c}\text { Bacillus } \\
\text { stearothermophilus }\end{array}$ & - & $\begin{array}{l}\text { D-PLA, film (TOC, } \\
\text { GPC, viscosity) }\end{array}$ & 60 & [79] \\
\hline Brevibacillus sp. & - & $\begin{array}{l}\text { L-PLA, film (TOC, } \\
\text { GPC, viscosity) }\end{array}$ & 60 & [78] \\
\hline $\begin{array}{c}\text { Aspergillus oryzae } \\
\text { RIB40 }\end{array}$ & Cutinase & $\begin{array}{l}\text { DL-PLA, turbidity } \\
\text { of emulsion }\end{array}$ & 37 & [80] \\
\hline $\begin{array}{l}\text { Aneurinibacillus } \\
\text { Aneurinilyticus }\end{array}$ & - & PLA film & 30 & [81] \\
\hline $\begin{array}{c}\text { Geobacillus } \\
\text { thermocatenulatus }\end{array}$ & Protease & L-PLA & 60 & [82] \\
\hline
\end{tabular}



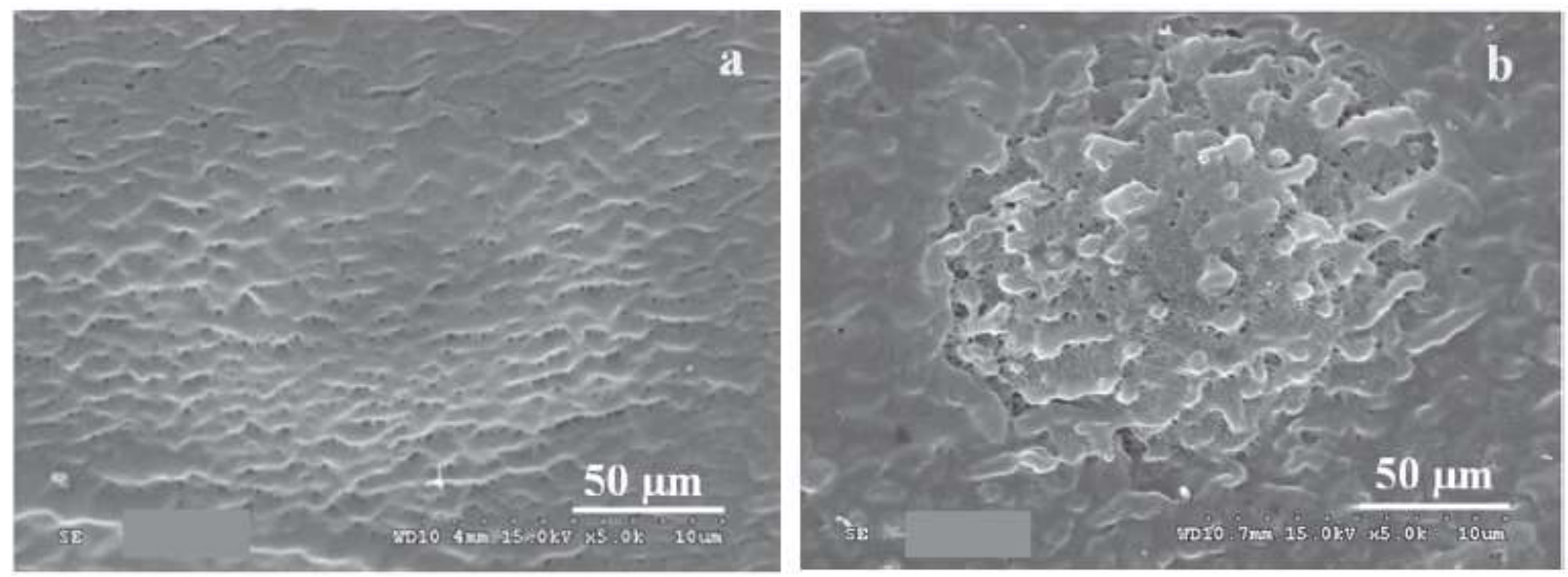

Fig. 6: SEM micrographs showing the surface morphology of PLA films after degradation by bacteria in 30 days at $30{ }^{\circ} \mathrm{C}$ in liquid medium: (a) surface structure without cell inoculations, $50 \mu \mathrm{m}$ (control no microorganism degradation), (b) surface structures with cell inoculation.

Table 4: Degradation time of some polymer films in soil.

\begin{tabular}{lll}
\hline Polymer film & Degradation span (days) & References \\
\hline Polylactic acid & $30-35$ & {$[84]$} \\
Polycaprolactone & $35-40$ & {$[85]$} \\
Chitin & $160-168$ & {$[86]$} \\
Cellulose & $28-30$ & {$[87]$} \\
Polyethylene & $60-65$ & {$[88]$} \\
Polyvinyl chloride & $90-95$ & {$[89]$} \\
Polystyrene & $70-85$ & {$[90]$} \\
\hline
\end{tabular}

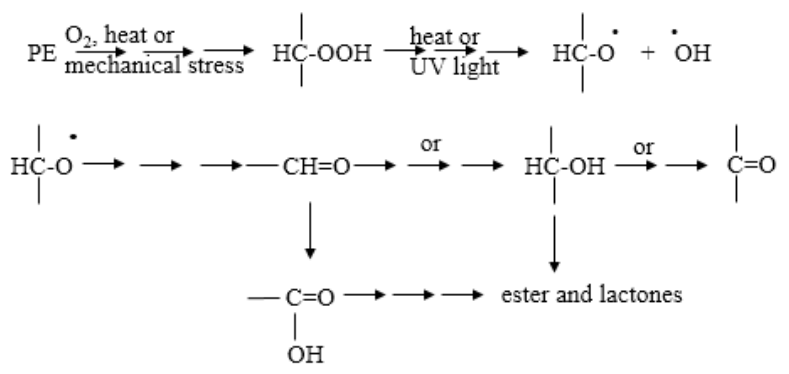

Fig. 7: Peroxidation mechanism of photodegradation of PE [92]. 


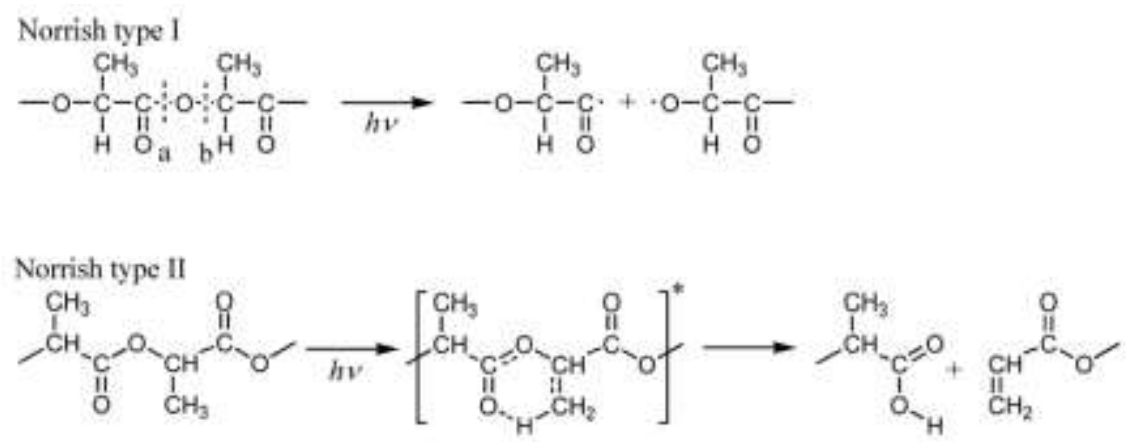

Fig. 8: Degradation of PLA by Norrish I and II type reaction [98].

\section{Conclusion}

In this review article, most common methods for polymer degradation that are familiar in practice such as thermal, photochemical, biochemical and enzymatic/catalytic processes have been discussed in brief taking polyethylene (PE) as a representative example of petro-based thermoplastics polymer and polylactic acid (PLA) as bio-based polymer. Comparing the results related to time, feasibility, cost and environmental concerns the biodegradation with composting would be the better solution of reducing plastic pollution for the sustainability. Results related to composting or biodegradation showed that the bio-based polymers such as PLA, polyhydroxybutyrate, copolyesters degrades easily in to environmentally compatible fragments/monomers as end products in comparison to petro-based polymers although there is very large gap in their mechanical properties. The identification of catalysts and enzymes to polymerize or crosslink the bio-based monomers to replace petro-based commodity polymers and finding the specific polymer eating (degrading) microorganisms would be the best way for the sustainability of polymer research.

\section{References}

[1] G-J. M. Gruter, The oppoertunity of sustainable materials, $5^{\text {th }}$ International Symposium on
Advances in Sustainable Polymers (ASP-19), Proceedings (2019) 2-3.

[2] V. M. Pathak and Navneet, Review on the current status of polymer degradation: a microbial approach, Bioresources and Bioprocessing 4(15) (2017) 1-31.

[3] A. A. Shah, F. Hasan, A. Hameed, and S. Ahmed, Biological degradation of plastics: a comprehensive review, Biotechnology Advantage 26(3) (2008) 246-265.

[4] A. A. Kumar, K. Katthick and K. P. Arumugam, Properties of biodegradable polymers and degradation for sustainable development, International Journal of Chemical Engineering and Applications 2(3) (2011) 164-167.

[5] V. Nagarajan, A. K. Mohanty, and M. Misra, Perspective on polylactic acid (PLA) based sustainable materials for durable applications: Focus on toughness and heat resistance, ACS Sustainable Chemistry and Engineering 4(6) (2016) 2899-2916.

[6] Z. Tadmor, and C. G. Gogos, Principles of polymer processing, United States of America, A John Wiley and Sons (2006).

[7] S. Sivaram, Aliphatic polysters: a platform for the design of sustainable materials, $5^{\text {th }}$ International Symposium on Advances in Sustainable Polymers (ASP-19), Proceedings, (2019) 6-7.

[8] S. Krishnan, P. Pandey, S. Mohanty, and S. K. Nayak, Toughening of polylactic acid: an overview of research progress, Polymer-Plasttic Technology and Engineering 75(15) (2015) 1-114.

[9] J. Zeng, K. Li, and A. Du, Compatibilization strategies in poly(lactic acid)-based blends, RSC Advances 5(41) (2015) 32546-32565. 
[10] K. S. Anderson, K. M. Schreck, and M. A. Hillmyer, Toughening polylactide, Journal Polymer Reviews 48(1) (2008) 85-108.

[11] R. M. Rasal, A. V. Janorkar, and D. E. Hirt, Poly(lactic acid) modifications, Progress in Polymer Science 35(3) (2010) 338-356.

[12] T. Kuroki, T. Sawaguchi, S. Niikuni and T. Ikemura, Mechanism for long chain branching in the thermal degradation of linear high-density polyethylene, Macromolecules 15 (1982) 14601464.

[13] M. Alauddin, I. A. Choudkury, M. A. Baradie and M. S. J. Hashmi, Plastics and their machining: a review, Journal of Material Processing and Technology 54 (1995) 40-46.

[14] G. Jandikova, P. Stoplova, A. Di-Martino, P. Stloukal, P. Kucharczyk, M. Machovsky and V. Sedlarik, Effect of a hybrid zinc stearate-silver system on the properties of polylactide and its abiotic and the biotic degradation and antimicrobial activity thereof, Chinese Journal of Polymer Science 36 (2018) 925-933.

[15] T. Iwata, Biodegradable and bio-based polymers: future prospects of eco-friendly plastics, Sustainable Chemistry 54 (2015) 2-8.

[16] M. Akiyama, T. Tsuge and Y. Doi, Environmental life cycle comparison of polyhydroxyalkanoates produced from renewable carbon resources by bacterial fermentation, Polymer Degradation and Stability 80 (2003) 183-194.

[17] E. T. H. Vink, K. R. Rabago, D. A. Glassner and P. R. Gruber, Catalysis for the conversion of biomass and its derivatives, Polymer Degradation and Stability 80 (2003) 403-419.

[18] Y. Doi, Microbial polyesters, VCH Publishers, New York (1990).

[19] B. Singh and N. Sharma, Mechanistic implications of plastic degradation: a review, Polymer Degradation and Stability 93 (2008) 561-584.

[20] T. F. Garrison, A. Murawski and R. L. Quirino, Bio-based polymers with potential for biodegradability, Polymers 8 (2016) 262-283.

[21] G. Bhandari, R. Pandit and N. L. Bhandari, Extraction and characterization of chitosan and preparation of nano-composite with resorcinol formaldehyde resin, Journal of Nepal Chemical Society 39 (2018) 53-61.

[22] K. Leja, and G. Lewandowicz, Polymer biodegradation and biodegradable polymers: a review, Polish Journal of Environmental Studies 19(2) (2010) 255-266.
[23] R. A. Kanaly, and S. Harayama, Biodegradation of high-molecular-weight polycyclic aromatic hydrocarbons by bacteria, Journal of Bacteriology 8 (2000) 2059-2067.

[24] R. Gautam, A. S. Bassi and E. K. Yanful, A review of biodegradation of synthetic plastic and Foams, Applied Biochemistry and Biotechnology 141(2007) 85-108.

[25] J. Gracida, J. Alba J. Cardoso and F. Perezguevara, Studies of biodegradation of binary blends of poly(3-hydroxybutyrate-co-3-hydroxyvalerate)

(PHBHV) with poly(2-hydroxyethylmetacrilate) (PHEMA), Polymer Degradation and Stability 83(2) (2004) 247-253.

[26] G. Swift, Requirements for biodegradable watersoluble polymers, Polymer Degradation and Stability 59 (1998) 19-24.

[27] Z. I. Gao, M. Amasaki and J. Nakada, A thermogravimetric study on thermal degradation of polyethylene, Journal of Analytical and Applied Pyrolysis 67 (2003) 1-9.

[28] J. D. Peterson, S. Vyazovkin and C. A. Wight, Kinetics of the thermal and thermo-oxidative degradation of polystyrene, polyethylene and polypropylene, Macromolecular Chemistry and Physics 202(6) (2001) 775-784.

[29] N. A. Sezgi, W. S. Cha, J. M. Smith and B. J. McCoy, Polyethylene pyrolysis: theory and experiments for molecular-weight-distribution kinetics, Industrial and Engineering Chemistry Research 37 (1998) 2582-2591.

[30] M. S. Abbas-Abadi, The effect of process and structural parameters on the stability, thermomechanical and thermal degradation of polymers with hydrocarbon skeleton containing PE, PP, PS, PVC, NR, PBR and SBR, Journal of Thermal Analysis and Calorimetry (2020) 1-16.

[31] J. Mikulec and M. Vrbova, Catalytic and thermal cracking of delected polyolefins, Clean Technologies and Environmental Policy 10 (2008) 121-130.

[32] A. Garforth, S. Fiddy, Y. H. Lin, A. Ghanbari, P. N. Sharatt and J. Dwyer, Production of hydrocarbons by catalytic degradation of high density polyethylene in a laboratory fluidized-bed reactor, Applied Catalysis A: General 169(2) (1998) 331-342.

[33] R. Bagri and P. T. Williams, Catalytic pyrolysis of polyethylene, Journal of Analytical and Applied Pyrolysis 63 (2002) 29-41.

[34] Cr. I. Simionescu, C. Vasile, P. Onu, M. Sabliovschi, G. Moroi, V. Barboiu, D. Ganju and 
M. Florea, Modification in thermal decomposition products of polymers by catalytic pyrolysis, Thermochimica Acta 134 (1988) 301-305.

[35] P. L. Beltrame, P. Carniti, G. Audisio and F. Bertini, Catalytic degradation of polymers: part IIdegradation of polyethylene, Polymer Degradation and Stability 26(3) (1989) 209-220.

[36] Y. Ishihara, H. Nanbu, T. Ikemura and T. Takesue, Catalytic decomposition of polyethylene using a tubular flow reactor system, Fuel 69(8) (1990) 978-984.

[37] D. S. Scott, S. R. Czernik, J. Piskorz and D. St. A. G. Radlein, Fast pyrolysis of plastic wastes, Energy Fuels 4(4) (1990) 407-411.

[38] Y. Ishihara, H. Nambu, T. Ikemura and T. Takesue, Effect of branching of polyolefin backbone chain on catalytic gasification reaction, Journal of Applied Polymer Science 38(8) (1989) 1491-1501.

[39] P. Gaca, M. Drzewiecka, W. Kaleta, H. Kozubek and K. Nowinska, Catalytic degradation of polyethylene over meso-porous molecular sieve MCM-41 modified with heteropoly compounds, Polish Journal of Environmental Studies 17(1) (2008) 25-31.

[40] J. Nisar, M. Ali and I. A. Awan, Catalytic thermal decomposition of polyethylene by pyrolysis gas chromatography, The Chilean Chemical Society 56(2) (2011) 653-655.

[41] A. Gregorova, M. Machovsky and R. Wimmer, Viscoelastic properties of mineral-filled poly(lactic acid) composites, International Journal of Polymer Science 2012 (2012) 1-6.

[42] H. Abe, N. Takahashi, K. J. Kim, M. Mochizuki and Y. Doi, Thermal degradation processes of end capped poly(L-lactide) in the presence and absence of residual zinc catalyst, Biomacromolecules 5 (2004) 1606-1614.

[43] X. Liu, Y. Zou, W. Li and G. Cao, Kinetics of thermo-oxidative and thermal degradation of poly(d,l-lactide) (PDLLA) at processing temperature, Polymer Degradation and Stability 91 (2006) 3259-3265.

[44] M. Pires, M. Murariu, A. M. Cardoso, L. Bonnaud and P. Dubois, Thermal degradation of poly(lactic acid)-zeolite composites produced by meltblending, Polymer Bulletin (2019) 1-27.

[45] F. D. Kopinke, M. Remmler, K. Mackenzie, M. Moder and $\mathrm{O}$. Wachsen, Thermal decomposition of biodegradable polyesters II poly(lactic acid), Polymer Degradation and Stability 53 (1996) 329342.
[46] O. Wachsen, K. H. Reichert, R. P. Kruger, H. Much and G. Schulz, Thermal decomposition of biodegradable polyesters-III. Studies on the mechanisms of thermal degradation of oligo-Llactide using SEC, LACCC and MALDI-TOF-MS, Polymer Degradation and Stability 55 (1997) 225231.

[47] F. Carrasco, J. Gamez-Perez, O. O. Santana and M. L. Maspoch, Enhanced general analytical equation for the kinetics of the thermal degradation of poly(lactic acid)/ montmorillonite nanocomposites driven by random scission, Polymer Degradation and Stability 101 (2014) 52-59.

[48] S. Majoni and A. Chaparadza, Thermal degradation kinetics study of polystyrene/ polystyrene/organophosphate composite, Thermochimica Acta, 662 (2018) 8-15.

[49] A. Marcilla, A. Gomez-Siurana and S. Menargues, Qualitative study of the evolution of the composition of the gas evolved in the thermal and HY-catalytic oxidative degradation of EVA copolymers, Thermochimica Acta 438 (2005) 155163.

[50] F. Signori, M. B. Coltelli and S. Bronco, Thermal degradation of poly(lactic acid) (PLA) and poly(butylene adipate-co-terephthalate) (PBAT) and their blends upon melt processing, Polymer Degradation and Stability 94 (2009) 74-82.

[51] H. Zou, C. Yi, L. Wang, H. Liu and W. Xu, Thermal degradation of poly(lactic acid) measured by thermogravimetry coupled to Fourier transform infrared spectroscopy, Journal of Thermal Analysis and Calorimetry 97 (2009) 929-935.

[52] M. H. Yang and Y. H. Lin, Measurement and simulation of thermal stability of poly(Lactic Acid) by thermogravimetric analysis, Journal of Testing and Evaluation 37(4) (2009) 1-7.

[53] H. Nishidaa, T. Moria, S. Hoshiharaa, Y. Fana, Y. Shiraic and T. Endoa, Effect of tin on poly(l-lactic acid) pyrolysis, Polymer Degradation and Stability 81 (2003) 515-523.

[54] H. Abe, N. Takahashi, K. J. Kim and M. Mochizuki, Thermal degradation processes of end capped poly(L-lactide) $\mathrm{s}$ in the presence and absence of residual zinc catalyst, Biomacromolecules 5 (2004) 1606-1614.

[55] L. Feng, S. Feng, X. Bian, G. Li and X. Chen, Pyrolysis mechanism of Poly(lactic acid) for giving lactide under the catalysis of tin, Polymer Degradation and Stability 157 (2018) 212-223.

[56] D. R. Witzke, R. Narayan and J. J. Kolstad, Reversible kinetics and thermodynamics of the 
homopolymerization of 1-lactide with 2ethylhexanoic acid Tin(II) salt, Macromolecules, 30 (1997) 7075-7085.

[57] Y. Wang, X. Wei, J. Duan, J. Yang, N. Zhang, T. Huang and Y. Wang, Greatly enhanced hydrolytic degradation ability of poly(L-lactide) achieved by adding poly(ethylene glycol), Chinese Journal of Polymer Science 35(3) (2017) 386-399.

[58] P. McKeown, M. Kamran, M. G. Davidson, M. D. Jones, L A. Roman-Ramirez and J. Wood, Organocatalysis for versatile polymer degradation, Green Chemistry 22 (2020) 3721-3726.

[59] D. Hadad, S. Geresh and A. Sivan, Biodegradation of polyethylene by the thermophilic bacterium Brevibacillus borstelensis, Journal of Applied Microbiology 98(5) (2005) 1093-1100.

[60] R. S. Devi, V. R. Kannan, D. Nivas, K. Kannan, S. Chandru and A. R. Antony, Biodegradationof HDPE by Aspergillus spp. from marine ecosystem of gulf of manner, India Marine Pollution Bulletin 96(1) (2015) 32-40.

[61] C. Abrusci, J. L. Pablos, T. Corrales, J. LopezMarin, I. Marin and F. Catalina, Biodegradation of photo-degraded mulching films based on polyethylenes and stearates of calcium and iron as pro-oxidant additives, International Biodeterioration and Biodegradation 65 (2011) 451-459.

[62] H. V. Sowmya, Ramalingappa, M. Krishnappa and B. Thippeswamy, Degradation of polyethylene by Trichoderma harzianum -SEM, FTIR and NMR analyses, Environmental Monitoring Assessment 186 (2014) 6577-6586.

[63] B. Nowak, J. Pajak, M. D. Bratkowicz and G. Rymarz, Microorganisms participating in the biodegradation of modified polyethylene films in different soils under laboratory conditions, International Biodeterioration and Biodegradation 65 (2011) 757-767.

[64] R. Usha, T. Sangeetha and M. Palaniswamy, Screening of polyethylene degrading microorganisms from garbage soil, Libyan Agriculture Research Center Journal International 2(4) (2011) 200-204.

[65] S. Bonhomme, A. Cuer, A. M. Delort, J. Lemaire, M. Sancelme and G. Scott, Environmental biodegradation of polyethylene, Polymer Degradation and Stability 81 (2003) 441-452.

[66] T. V. Sepulveda, G. S. Castaneda, M. G. Rojas, A. Manzur and E. F. Torresi, Thermally treated low density polyethylene biodegradation by Penicillium pinophilum and Aspergillus niger,
Journal of Applied Polymer Science, 83 (2002) 305-314.

[67] A. Corti, S. Muniyasamy, M. Vitali, S. H. Imamc and E. Chiellini, Oxidation and biodegradation of polyethylene films containing pro-oxidant additives: synergistic effects of sunlight exposure, thermal aging and fungal biodegradation, Polymer Degradation and Stability 95 (2010) 1106-1114.

[68] R. E. Drumright, Gruber, R. Patrick and D. E. Henton, Polylactic acid technology, Advanced Materials 12 (2000) 1841-1846.

[69] X. Qi, Y. Ren and X. Wang, New advances in the biodegradation of poly(lactic) acid, International Biodeterioration and Biodegradation 117 (2017) 215-223.

[70] A. Jarerat, Y. Tokiwa and H. Tanaka, Microbial poly(L-lactide)-degrading enzyme induced by amino acids, peptides, and poly(L-amino acids), Journal of Polymers and the Environment 12 (2004) 139-146.

[71] Y. Tokiwa and A. Jarerat, Biodegradation of poly(L-lactide), Biotechnology Letters 26 (2004) 771-777.

[72] J. D. Gu, Microbiological deterioration and degradation of synthetic polymeric materials: recent research advances, International Biodeterioration and Biodegradation 52 (2003) 69-91.

[73] R. Lipsa, N. Tudorachi, R. N. Darie-Nita, L. Oprica, C. Vasile and A. Chiriac, Biodegradation of poly(lactic acid) and some of its based systems with Trichoderma viride, International Journal of Biological Macromolecules 88 (2016) 515-526.

[74] T. Maharana, B. Mohanty and Y. S. Negi, Meltsolid polycondensation of lactic acid and its biodegradability, Progress in Polymer Science 34 (2009) 99-124.

[75] Y. Ikura and T. Kudo, Isolation of a microorganism capable of degrading poly-(Llactide), Journal of General Applied Microbiology 45 (1999) 247-251.

[76] H. Pranamuda, A. Tsuchii and T. Tokiwa, Poly (Llactide) degrading enzyme produced by Amycolatopsis sp., Macromolecular Bioscience 1 (2001) 25-29.

[77] A. Jarerat and Y. Tokiwa, Biodegradation of poly(l-lactide), Biotechnology Letters 25 (2003) 401-404.

[78] A. Jarerat, Y. Tokiwa and H. Tanaka, Poly(1lactide) degradation by Kibdelosporangium aridum, Biotechnology Letters 25 (2003) 20352038. 
[79] K. Tomita, T. Tsuji, H. Nakajima, Y. Kikuchi, K. Ikarashi and N. Ikeda, Degradation of poly (Dlactic acid) by a thermophile, Polymer Degradation and Stability 81 (2003) 167-171.

[80] H. Maeda, Y. Yamagata, K. Abe, F. Hasegawa, M. Machida, R. Ishioka, K. Gomi and T. Nakajima, Purification and characterization of a biodegradable plastic-degrading enzyme from Aspergillus oryzae, Applied Microbiology and Biotechnology 67 (2005) 778-788.

[81] K. Chaisu, A. L. Charles, Y. K. Guu and C. H. Chiu, Microbial degradation of poly lactic acid (PLA) by Aneurinibacillus aneurinilyticus, Journal of Biobased Materials and Bioenergy 7 (2013) 509-511.

[82] K. Tomita, T. Nakajima, Y. Kikuchi and N. Miwa, Degradation of poly(L-lactic acid) by a newly isolated thermophile, Polymer Degradation and Stability 84 (2004) 433-438.

[83] H. Pranamuda, Y. Tokiwa and H. Tanka, Polylactide degradation by an Amycolatopsis sp, Applied and Environmental Microbiology 63(4) (1997) 1637-1640.

[84] V. Sedlarik, N. Saha, J. Sedlarikova and P. Saha, Biodegradation of blown films based on poly(lactic acid) under natural conditions, Macromolecular Symposia 272 (2008) 100-103.

[85] K. Krasowskaa, A. Heimowska and M. Morawska, Environmental degradability of polycaprolactone under natural conditions, E3S Web of Conferences, 10 (2016) 81-87.

[86] I. M. Laham and T. C. Lee, Biodegradability of chitin and chitosan containing films in soil environment, Journal of Enviromnental Polymer Degradation 3(1) (1995) 31-36.

[87] G. Zhao, X. Lyu, J. Lee, X. Cui and W. N. Chen, Biodegradable and transparent cellulose film prepared eco-friendly from durian rind for packaging application, Food Packaging and Shelf Life 21 (2019) 1-6.

[88] G. J. L. Griffin, Degradation of polyethylene in compost burial, Journal of Polymer 57 (2007) 281286.

[89] L. Giacomucci, N. Raddadi, M. Soccio, N. Lotti and F. Faa, Polyvinyl chloride biodegradation by Pseudomonas citronellolis and Bacillus flexus, New Biotechnology 52 (2019) 35-41.

[90] B. T. Hoa, T. K. Robert and S. Lucas, Overview on biodegradation of polystyrene and modified polystyrene: the microbial approach, Critical
Reviews in Biotechnology 38(2) (2018) 308-320.

[91] V. P. Ranjan and S. Goel, Degradation of lowdensity polyethylene film exposed to UV radiation in four environments, Journal of Hazardous, Toxic and Radioactive Waste 23(4) (2019) 1-11.

[92] D. M. Wiles and G. Scott, Polyolefins with controlled environmental stability, Polymer Degradation and Stability 91 (2006) 1581-1592.

[93] S. S. Fernando, P. A. Christensen, T. A. Egerton and J. R. White, Carbon dioxide evolution and carbonyl group development during photodegradation of polyethylene and polypropylene, Polymer Degradation and Stability 92 (2007) 2163-2172.

[94] S. Ghafoori, M. Mehrvar and P. K. Chan, Freeradical-induced degradation of aqueous polyethylene oxide by $\mathrm{UV} / \mathrm{H}_{2} \mathrm{O}_{2}$ : experimental design, reaction mechanisms and kinetic modeling, Industrial \& Engineering Chemistry Research 51 (2012) 14980-14993.

[95] D. Briassoulis, A. Aristopoulou, M. Bonora and I. Verlodt, Degradation characterisation of agricultural low-density polyethylene films, Biosystems Engineering 88(2) (2004) 131-143.

[96] L. Zaidi, M. Kaci, S. Bruzaud, A. Bourmaud and Y. Grohens, Effect of natural weather on the structure and properties of polylactide/Cloisite 30B nanocomposites, Polymer Degradation and Stability 95 (2010) 1751-1758.

[97] S. Bocchini, K. Fukushima, A. D. Blasio, A. Fina, A. Frache and F. Geobaldo, Polylactic acid and polylactic acid-based nanocomposite photooxidation, Biomacromolecule 11 (2010) 2919-2926.

[98] W. Sakai and N. Tsutsumi, Photodegradation and radiation degradation, John Wiley and Sons, Inc. (2010) 413-421.

[99] A. Copinet, C. Bertrand, A. Longieras, V. Coma and Y. Couturier, Photodegradation and biodegradation study of a starch and poly(lactic acid) coextruded material, Journal of Polymers and the Environment 11(4) (2003) 169-179.

[100] R. W. J. Westerhout, J. Waanders, J. A. M. Kuipers and W. P. M. van Swaaij, Kinetics of the low-temperature pyrolysis of polyethene, polypropene and polystyrene modeling, experimental determination and comparison with literature data: review, Industrial and Engineering Chemistry Research 36 (1997) 1955-1964. 